\title{
NOTES ON PLYMOUTH MYSIDACEA
}

\author{
By Olive S. Tattersall
}

Whilst working recently at the Plymouth Marine Laboratory ${ }^{1}$ I was, very kindly, given the opportunity of examining the mysids captured during a night cruise carried out by Mr P. G. Corbin around the Eddystone Lighthouse on 26/27 August I936.

Eight $30 \mathrm{~min}$. standard oblique hauls were taken with a 2-metre stramin ring trawl, at stations situated in a circle around the lighthouse, starting 2 miles due north-east at 8.I 7 p.m. The second haul was taken 2 miles due east and so on, passing from station to station in a clockwise direction, the last haul being taken due north at 4 a.m. The weather was fine and clear, with a clear half-moon which set at $15 \mathrm{~min}$. past midnight.

The collection included nine species, only four of which-Anchialina agilis, Leptomysis gracilis, Gastrosaccus normani and Schistomysis ornata-were present in any numbers, whilst the other five were represented by only a few isolated individuals.

Adult mysids in the open ocean live by day, for the most part, either on the bottom or swimming about in the lowest levels of the water just clear of the bottom. It has been shown by many workers (e.g. Russell, I925, I927, I928, I93 I ; Tattersall, I936, I938; Fage, I933) that many species of mysids perform regular migrations to higher levels during hours of darkness, and sometimes actually reach the surface. Shortly before dawn they begin to move downward again, and by daylight all but immature animals have regained their habitat at the bottom. In addition to this nightly upward movement, many mysids become markedly planktonic during their breeding season, and in many species the females rise to the surface to release the young. These juvenile animals remain pelagic but gradually seek deeper water as they approach maturity (Fage, I932, I933; Tattersall, I938).

In oblique hauls such as were used on the Eddystone cruise, it is not possible to say at which levels the animals were mainly taken, but certain points arise which bear out the observations of earlier workers. The first haul was taken before daylight had completely faded and the upward migration had not yet begun, for only five specimens were taken. At 9.I4 p.m., when the second haul was taken, $45^{8}$ mysids were captured, of which more than half were immature. Hauls 3 and 4 showed a steady increase in numbers but, for some reason, the numbers in hauls 5 and 6 fell considerably, rising again sharply in hauls 7 and 8 .

The hauls are analysed in Table I. Hauls 4 to 8 were sub-sampled, onetenth being counted.

1 I should like to express my gratitude to the Director, Mr F. S. Russell, F.R.S., and to $\mathrm{Mr}$ G. M. Spooner, for all the help they have so kindly given me. 
The majority of the mysids collected during the night were immature and practically all the adults were actively breeding, the males large and well developed and the females with full brood-pouches. The proportion of adults increased markedly in the later hauls. Whilst sorting the collection I was particularly struck by the preponderance of males among the adults. The numbers of the sexes were counted in Gastrosaccus normani. I found that in the early part of the night there was an average of three adult males to every adult female, with the sexes more or less evenly balanced in the juveniles. In the later hauls more females appeared and the males outnumbered them by only two to one, while the juveniles were again present in almost equal numbers.

Amongst the specimens of $G$. normani I was interested to find three adults which possessed reflexed lobes on the posterior margin of the carapace but

\section{Table I. Numbers of Mysidacea Species Captured IN EACH HaUl of THe Eddystone CRUiSE}

\begin{tabular}{|c|c|c|c|c|c|c|c|c|}
\hline $\begin{array}{c}\text { Haul } \\
\text { Time }\end{array}$ & $\begin{array}{l}\text { I } \\
8.17- \\
8.56\end{array}$ & $\begin{array}{l}2 \\
9.14- \\
9.45\end{array}$ & $\begin{array}{c}3 \\
\text { I0.0I- } \\
\text { I0.34 }\end{array}$ & $\begin{array}{c}4 \\
\text { IO. } 58- \\
\text { II. } 34\end{array}$ & $\begin{array}{c}5 \\
00.55- \\
\text { oI.3I }\end{array}$ & $\begin{array}{c}6 \\
01.5 \mathrm{I}- \\
02.22\end{array}$ & $\begin{array}{c}7 \\
02.50- \\
05.26\end{array}$ & $\begin{array}{c}8 \\
04.01- \\
04 \cdot 36\end{array}$ \\
\hline Anchialina agilis & I & 63 & I8I & 790 & 580 & 480 & I 290 & I 430 \\
\hline Schistomysis ornata & - & 59 & 36 & 120 & I30 & 320 & 260 & 370 \\
\hline Leptomysis gracilis & 3 & 146 & I36 & 510 & 270 & 280 & 740 & II 60 \\
\hline $\begin{array}{l}\text { Gastrosaccus normani } \\
\text { Erythrops elegans }\end{array}$ & - & $\left\{\begin{array}{c}240 \\
90 \\
90 \text { juv. } \\
I\end{array}\right.$ & $\begin{array}{l}52 \text { o } \\
\text { I7 के } \\
83 \text { juv. } \\
-\end{array}$ & $\begin{array}{r}\text { I8 o } \\
7 \text { o } \\
23 \text { juv. } \\
-\end{array}$ & $\begin{array}{l}\text { II } 0 \text { o } \\
4 \text { के } \\
\text { II juv. } \\
-\end{array}$ & $\begin{array}{rl}12 & 0 \\
7 & \$ \\
19 & \text { juv. } \\
2\end{array}$ & $\begin{array}{l}200 \\
\text { II } 9 \\
\text { I5 juv. } \\
6 \\
\text { (I with } \\
\text { parasite) p }\end{array}$ & $\begin{array}{c}\text { 13 ô } \\
7 .+ \\
9 \text { juv. } \\
8 \\
\text { (2 with } \\
\text { parasite) }\end{array}$ \\
\hline Siriella norvegica & - & 2 & I & 一 & $\left(\begin{array}{c}\mathrm{I} \\
23 \mathrm{~m} .)\end{array}\right.$ & I & - & $\begin{array}{c}\text { I } \\
\text { (juv.) }\end{array}$ \\
\hline S. jaltensis & 一 & I & - & 一 & $\begin{array}{l}\text { I } \\
\text { (juv.) }\end{array}$ & - & - & 一 \\
\hline $\begin{array}{l}\text { Mysidopsis gibbosa } \\
\text { M. angusta }\end{array}$ & - & $\begin{array}{l}2 \\
6\end{array}$ & I & - & I & - & - & - \\
\hline
\end{tabular}

which, in every other particular, conformed with the published descriptions of the species. My husband (Tattersall, I9I2, p. 4I) recorded similar specimens from the west coast of Ireland, and among his unpublished notes I find a record that he had examined a male and a female specimen from Plymouth, both with reflexed lobes, but which were 'undoubtedly $G$. normani'. It was at one time thought that the presence of reflexed lobes was constant for certain species, and that they never occurred in G. normani. Acting on this assumption, Kossmann (I880, p. 95) founded the genus Haplostylus for those species which had no lobes on the posterior margin of the carapace, and he placed G. normani in this genus. Since it is now clear that the character upon which the genus was founded is variable the name Haplostylus $\left(\dot{\alpha} \pi \lambda\right.$ óos $\left.^{\prime}=\operatorname{simple}\right)$ ceases to have any significance and the species must be referred to Sars's original genus Gastrosaccus. 
In the material from haul 7, I found an adult female of Erythrops elegans, bearing a large male specimen of the parasitic copepod Aspidoecia normani Giard \& Bonnier attached by a short stalk to the middle of the dorsal surface of the first abdominal somite. In haul 8, I found two more specimens of Erythrops elegans which were parasitized by the same species. One of the Aspidoecia was a male attached to the dorsal surface of the second abdominal somite, and the other was a large female with eight to nine ovisacs attached to the first abdominal somite. Among about twenty specimens of Erythrops elegans dredged off Rame Head on 6 June 1948, I found one adult female bearing a female Aspidoecia normani on the dorsal surface of the second abdominal somite. Only one of the hosts was a male which appeared to be fully developed. It is significant that although unparasitized females captured at the same time all had their brood-pouches full of eggs or embryos, all the parasitized females had empty brood-pouches.

A. normani has been recorded from Norwegian waters on five species of Erythrops. Scott (I902, p. 480) recorded it from the Firth of Forth on $E$. elegans and $E$. microps ( $=E$. goësii) but, although its host species are known from many localities around our coasts, I can find no further record of it from British waters. Its occurrence in two gatherings taken nearly I2 years apart suggests that it may occur regularly in the Plymouth area.

Although the Eddystone cruise yielded representatives of only nine species, there have, up to the present, been no fewer than twenty-six species of mysids recorded from the Plymouth area. I have therefore drawn up a key for the identification of the genera to which they belong, with supplementary keys ${ }^{1}$ from which it should be possible to identify any of the species mentioned. I have included among these a few species which have not yet been recorded from the Plymouth area, but which may reasonably be expected to be found there.

Descriptions of genera and species may be found in the standard works of Sars (1870-9) and Zimmer (I909). The keys given by Zimmer (1933) for the North and Baltic Seas, and in particular the sketches which accompany them, are also very useful.

The nomenclature here conforms with that adopted in the Ray Society Monograph (Tattersall, in Press).

\section{Key to the Mysidacea Found in the Plymouth Area}

\section{Genera}

I. Telson cleft.

Telson entire (one species with very small naked incision). $\quad . \quad . \quad . \quad 8$

2. Scale setose all round. Carpus and propodus of third thoracic limb fused, much enlarged and not subdivided.

Scale with outer margin without setae. Third carpopropodite subdivided into three or more segments, not much enlarged.

3. Exopod of uropod with spines arming outer margin. . . . . . 4 Exopod of uropod setose all round.

1 The supplementary keys are given in taxonomic order. 
4. Short robust form. Posterior margin of carapace transverse and straight. Inner margin of endopod or uropod with many spines in series right to distal end. Telson with many spines in series. Carpopropodus of thoracic endopods subdivided into three or four segments.

Anchialina Norman \& Scott

[A. agilis (G. O. Sars)]

Long slender form. Posterior margin of carapace emarginate. Few large spines on inner margin of endopod of uropod. Few spines on lateral margins of telson, not in series. Carpopropodus of thoracic endopods subdivided into many segments. Gastrosaccus Norman [see p. 788]

5. Scale ovate, with proximal part of outer margin naked and not ending in a thorn.

Hemimysis G. O. Sars [H. lamornae (Couch)]

Naked portion of outer margin of scale ending in a thorn or spine. . . 6

6. Scale long, slender, with naked outer margin terminating in articulated spine; its apex little, if at all, longer than spine. Fourth pleopod of male with exopod very long, styliform, seven-segmented; distal segment terminating in a knob, armed a short distance from its apex with dense, spirally arranged spinules, but no 'pincer' setae. Praunus Leach [see p. 787]

Scale oval, its apex extending far beyond terminal thorn. Fourth pleopod of male very long; armed distally with two long setae which form a weak kind of 'pincers'.

7. First subsegment of carpopropodus of thoracic limbs short, swollen, very setose and cut off obliquely from more distal joints.

Paramysis Czerniavsky [see p. 787]

First subsegment of carpopropodus of third to eighth thoracic limbs longer than more distal segments, not swollen and cut off by transverse articulation.

Schistomysis Norman [see p. 787 ]

8. Scale with outer margin naked and ending in a thorn. . . . . . $\quad$. 9

Scale setose all round. . . . . . . . . . . . . . ro

9. Telson short, triangular, lateral margins naked, apex narrow, transverse, armed with 2-4 strong spines. Eye pigment very red.

Erythrops G. O. Sars [see p. 786]

Telson long, linguiform with rounded apex; armed all round with many spines usually arranged in series. Exopod of uropod two-segmented; inner margin of endopod with many spines.

Siriella Dana [see p. 785]

Io. Tarsus, three- to four-segmented. Pleopods of male biramous, natatory, with only setae modified. (Telson long.) . . . . .

Tarsus six- to eight-segmented. Pleopods of male rudimentary; fourth pair long, with modified setae. .

II. Scale very slender and rather long. Telson more parallel-sided, armed with many spines in series. (Carpopropodus of third to eighth thoracic limbs three-segmented.)

Leptomysis G. O. Sars [see p. 786]

Scale lanceolate. Telson triangular, tapering to narrow truncate or rounded apex (one British species has small unarmed median notch); lateral margins armed with small spines not in series. (Telson hollowed into a trowelshape.)

Mysidopsis G. O. Sars [see p. 786]

I2. Scale long and narrow. Telson long, tapering, with many spines arming lateral margins and apex. Fourth pleopods of male very long, armed distally with two equal setae. 
Scale small and narrow. Telson short, lateral margins unarmed, each ending distally in large spine; apex rounded, armed with dense comb of regular spines. Fourth male pleopod long, with 'pincer' setae. (Eye-stalks long, cylindrical.)

13. Distal end of scale acutely pointed.

Mesopodopsis Czerniavsky

[M. slabberi (van Beneden)]

Distal end of scale rounded.

Acanthomysis Czerniavsky

[A. longicornis (Milne Edwards)]

$[N$. integer (Leach) (=vulgaris J. V. Thompson)]

\section{Siriella Dana, I850}

I. Rostrum long and tapering, extending to distal end of second segment of antennular peduncle. Apex of telson with four (rarely three) spinules between the two large apical spines.

$S$. armata (Milne-Edwards)

Rostrum short and pointed, reaching only half-way along the first segment of antennular peduncle. Telson with three apical spinules.

2. Terminal spinules of telson of equal length. Distal segment of exopod of uropod not twice as long as broad.

S. clausii G. O. Sars

Terminal spinules of telson in form of trident with median one considerably longer than the other two. Distal segment of exopod of uropod twice (or nearly) as long as broad.

3. Outer margin of exopod of uropod with 9-15 spines. Spines arming inner margin of endopod of uropod increasing evenly in size distally without smaller spines between.

S. jaltensis Czerniavsky

Outer margin of exopod of uropod with I I-I2 spines. Spines arming inner margin of endopod of uropod arranged in series proximally with the 8-10 distal spines equal and no small ones between. (Rostrum curved downward and appearing short in dorsal view.) S. jaltensis var. brooki Norman

Outer margin of exopod of uropod with I5-23 spines; spines on inner margin of endopod arranged in series throughout. Very like $S$. clausii in general appearance but nearly twice as large.

S. norvegica G. O. Sars

\section{Gastrosaccus Norman, I868}

Posterior margin of carapace with fringe of eight to ten delicate prolongations. Antennular peduncle without conspicuous setae. Apex of scale equal in length to terminal spine of outer margin. Telson with 6-8 large spines on each lateral margin. Fifth abdominal segment laterally compressed with median dorsal keel produced into a spine posteriorly. G. spinifer (Goës)

Posterior margin of carapace usually with two reflexed lobes. Inner margins of second and third segments of antennular peduncle, each with three to five long plumose setae. Apex of scale shorter than spine terminating outer margin. Telson with 6 spines on each lateral margin. (Endopod of uropod with 6 spines on inner margin.)

G. sanctus (van Beneden)

Posterior margin of carapace usually without reflexed lobes. Inner margins of second and third segments of antennular peduncle each with a single plumose seta. Apex of scale longer than terminal spine of outer margin. Telson with about to spines on each lateral margin. (Endopod of second pleopod of male sigmoid and not natatory. Eyes small.) 


\section{Erythrops G. O. Sars, 1869}

I. Outer margin of antennal scale serrated. Inner margin of endopod of uropod minutely serrulated under the setae.

Outer margin of antennal scale not serrated. Inner margin of endopod of uropod usually not serrulated.

2. Distal serration of outer margin of scale longer than apex of scale. Endopod of eighth thoracic limb variable in length, but not extending beyond posterior margin of abdomen.

E. serrata (G. O. Sars)

Distal serration of outer margin of scale shorter than apex of scale. Endopod of eighth thoracic limb reaching beyond distal tip of uropod.

E. abyssorum G. O. Sars

3. Inner margin of endopod of uropod minutely serrulated. .

Inner margin of endopod of uropod without serrulation. (Endopod of eighth thoracic limb extending to posterior end of fifth abdominal segment. Eyes large, close together; short, linguiform rostrum produced forward between the eyes; antennal scale considerably longer than antennular peduncle.)

E. erythrophthalma (Goës)

4. Eyes large, set well apart, antennal scale a little longer than antennular peduncle. Endopod of eighth thoracic limb usually short, barely reaching end of fourth abdominal segment. (Animals small and comparatively robust.)

E. elegans (G. O. Sars)

Eyes small, set widely apart; antennal scale short, subequal in length to the antennular peduncle. Endopod of eighth thoracic limb reaching to posterior end of telson.

E. microps (G. O. Sars)

\section{Leptomysis G. O. Sars, I869}

I. Integument covered with scales which are upturned distally, giving the animals a hispid appearance. Rostrum acutely pointed with convex sides and a deep notch at each side at its base. (Animals very transparent and slender. Marked constriction in telson marking insertion of distal pair of long marginal spines. Statocyst large.)

L. gracilis (G. O. Sars)

Integument smooth. Rostrum without lateral notches.

2. Animals longer and more slender. Body covered all over with fine branches of brown pigment. Rostrum with straight sides. (Limbs stouter and statocyst smaller than in L. gracilis. No marked constriction in the telson.)

L. mediterranea G. O. Sars

Animals much shorter, more compact and robust than other two species. Colour milky, pale rosy markings. Rostrum short, with curved margins. (Eyes closely set, thick and short. Telson short and broad without constriction distally.)

L. lingvura (G. O. Sars)

Mysidopsis G. O. Sars, I864

I. Telson with no trace of median cleft.

Apex of telson with short unarmed notch. (Lateral margins of telson armed with 14-I8 spines which increase in size distally. Cleft wedge-shaped without plumose setae.)

M. angusta G. O. Sars

2. Rostrum broadly triangular. Telson triangular, rather long; lateral margins straight, converging to narrow truncate apex with a large spine at each 
corner; 8-10 spines on each lateral margin. Carapace without median swellings.

M. didelphys (Norman)

Rostrum very small, in form of very obtuse triangle. Telson short, with lateral margins concave, narrowing to rounded apex armed with two small median spinules; spines on lateral margins very small. Two conspicuous median swellings on carapace appearing as humps in lateral view.

M. gibbosa G. O. Sars

Paramysis Czerniavsky, I882

Short robust form; length $7 \mathrm{~mm}$. Uropod armed along whole length of inner margin with 28-30 spines arranged in series. Telson narrow, with narrow cleft not widely open.

P. $\operatorname{arenosa}$ (G. O. Sars)

Longer and more slender form; length II mm. Endopod of uropod with 9-1o subequal spines along distal two-thirds of inner margin. Telson wider, cleft widely open with sides nearly straight. P. helleri (G. O. Sars)

\section{Schistomysis Norman, I89?}

Note. The spines arming the inner margins of the endopods of the uropods are fewer and less crowded, and the cleft of the telson less deep in immature animals than in adults in this genus. As a result there may be some difficulty in identifying immature specimens.

I. Eyes long and narrow. Carpopropodus with nine subsegments. (Body very slender, expecially anteriorly. Cleft of telson fairly wide with straight sides. Spines arming inner margin of endopod of uropod very dense.)

S. spiritus (Norman)

Eyes not long and narrow. Carpopropodus with five to six subsegments.

2. Eyes short and thick and large, not extending much beyond lateral margin of carapace. Spines arming inner margin of endopod of uropod not dense; one situated terminally, then a space, then I spine, then another space and then regular row to statocyst. Carpopropodus with five subsegments (rarely six). (Body robust. Cleft of telson deep with convex margins.)

\section{S. ornata (G. O. Sars)}

Eyes nearly globular, moderately large. Endopod of uropod markedly curved, armed on inner margin with I very long terminal spine, then a gap to about half-way along margin, then 3-4 very long slender spines, and then a close row of spines in series back to the statocyst. Carpopropodus with six subsegments (rarely five).

S. parkeri Norman

A fourth species, S. kervillei (G. O. Sars), has not yet been recorded from Plymouth, though it has been taken in the mouth of the Seine and off the coast of Kent. It is very closely similar to $S$. ornata and appears to have similar habits to that species. Although certain of its characters are quite constant, and the two species may be distinguished when they are together, it is extremely difficult to set out shortly any definite characters whereby they may be distinguished. The most reliable guide is in the arrangement of the chromatophores.

\section{Praunus Leach, I8I4}

Note. The specific characters differentiating the species of this genus are not attained until the animals are fully grown, though they may be sexually mature. The proportions of the antennal scale, the number of sub-segments in the tarsus of the thoracic limbs and the depth 
of the cleft of the telson vary considerably with age, and it is very difficult to distinguish between specimens of $P$. flexuosus, which are not fully mature, and specimens of $P$. neglecta. The only reliable guide lies in the distribution of the chromatophores, which remains constant throughout life (Keeble \& Gamble, 1904, p. 33I).

I. Apex of scale shorter than terminal spine of outer margin. (Body long and slender. Eyes well developed with long cylindrical eye-stalks; whole of cornea and part of eye-stalks extending well beyond lateral margins of carapace. Scale very long and slender, seven to nine times as long as broad; more than twice as long as antennular peduncle. Telson cleft to one-sixth of total length. Endopod of uropod with IO-I2 spines on inner margin. Tarsus of third to eighth thoracic limbs usually with six subsegments, eighth with five.)

$P$. flexuosus (Müller)

2. Apex of scale longer than terminal spine of outer margin. Somewhat smaller than $P$. flexuosus, but very similar in form. Antennal scale five times as long as broad; less than twice as long as antennular peduncle. Apex slightly longer than terminal spine. Endopod of uropod with I2 spines on inner margin. Telson cleft to one-fifth of total length. Tarsus of thoracic limbs five-segmented (eighth four-segmented).

$$
\text { P. neglectus (G. O. Sars) }
$$

Body shorter and less slender than preceding species. Antennal scale four times as long as broad, and about one-third longer than the antennular peduncle. Apex produced beyond terminal spine to about two to three times length of spine. Endopod of uropod with 6-7 spines on inner margin. Telson cleft to nearly one-third of total length. Tarsus of thoracic limbs four-segmented.

Heteromysis S. I. Smith, I874

I. Telson with spines only on the distal portion of the lateral margins. . Telson with spines (18-20) along whole length of lateral margins; apical lobes with 2 spines, the inner longer than the outer. Endopods of uropods with spines along whole length of inner margin. $\quad H$. armoricana Nouvel

2. Endopod of uropod with $\mathrm{I}_{7-20}$ spines along whole of inner margin. Lateral margins of telson with I4-I8 spines on distal portion; apical lobes with 2 spines, the inner longer than the outer. Eye not very small.

H. formosa S. I. Smith

Endopod of uropod with single spine near statocyst. Lateral margins of telson armed distally with 9-I3 spines; apical lobes narrow and acute, armed with 2 spines, the outer twice as long as the inner. Eyes very small.

H. microps (G. O. Sars)

\section{SUMMARY}

The mysid fauna of eight night hauls made near the Eddystone Lighthouse is analysed.

Keys are given for the identification of Mysidacea which have been recorded from, or are likely to occur in, the Plymouth area. 


\section{REFERENCES}

FAGE, L., 1932. La migration verticale saisonnière des Mysidacés. C.R. Acad. Sci. Paris, T. 194, pp. 313-15.

- 1933. Pêches planktoniques à la lumière effectuées à Banyuls-sur-Mer et à Concarneau. III. Crustacés. Arch. Zool. exp. gén., T. 76, pp. I05-248.

Keeble, F. \& Gamble, F. W., I904. The colour physiology of higher Crustacea. Phil. Trans. Roy. Soc., London, Ser. B, Vol. 196, pp. 295-388.

Kossmann, R., I880. Malacostraca Anomura in: Zoologische Ergebnisse einer Reise in die Küstengebiete des Rothen Meeres. Zweite Hälfte, Lf. I, pp. 67-I40.

RuSSELL, F. S., 1925. The vertical distribution of marine macroplankton. An observation on diurnal changes. 'Fourn. Mar. Biol. Assoc., Vol. xIII, pp. 769-809.

- I927. The vertical distribution of marine macroplankton. V. The distribution of animals caught in the ring-trawl in the daytime in the Plymouth area. Fourn. Mar. Biol. Assoc., Vol. xIv, pp. 557-608.

- 1928. The vertical distribution of marine macroplankton. VI. Further observations on diurnal changes. Fourn. Mar. Biol. Assoc., Vol. xv, pp. 8I-IO3.

- I93I. The vertical distribution of marine macroplankton. XI. Further observations on diurnal changes. Fourn. Mar. Biol. Assoc., Vol. xviI, pp. 767-84.

SARS, G. O., I870-9. Carcinologiske Bidrag til Norges Fauna. I. Monographie over de ved Norges Kyster foregommende Mysider. 3 vols. Christiania.

Scotт, T., I902. Notes on gatherings of Crustacea collected by the Fishery Steamer 'Garland' and the steam trawlers 'Star of Peace' and 'Star of Hope' of Aberdeen, during the year I90I. Ann. Rep. Fishery Board Scotland, No. 20, Part III (Scientific Investigations), pp. 447-85.

Tattersall, W. M., I9I2. Clare Island Survey. Nebaliacea, Cumacea, Schizopoda and Stomatopoda. Proc. R. Irish Acad., Vol. 3I, pt. 4I, ro pp.

— 1936. Mysidacea and Euphausiacea. Rep. Gt Barrier Reef Exp., Vol. v, pp. $143-176$.

— 1938. The seasonal occurrence of mysids off Plymouth. Fourn. Mar. Biol. Assoc., Vol. xxiII, pp. 43-56.

Zimmer, C., I909. Schizopoden in Nordisches Plankton, Bd. 6, I78 pp.

- 1933. Mysidacea in Die Tierwelt der Nord- und Ostsee, Lf. XxIII, Teil X $\mathrm{X}_{3}$, pp. 29-69. 